\title{
CHANGES IN PRODUCTIVITY AND YIELD COMPONENTS IN FOUR FIELD CROPS SOWN ON DAMAGED BY FROST CROPS OF WINTER OILSEED CANOLA
}

\author{
Grozi Delchev \\ Department of Plant Production, Faculty of Agriculture, Trakia University, Stara Zagora, \\ Bulgaria. E-mail: delchevgd@dir.bg
}

\begin{abstract}
During 2016 - 2018 was conducted a field experiment. On areas with damaged by frost winter oilseed canola, were sowed and 4 field crops: 1 chickpea cultivar - Kabule (Cicer arietinum L.); 1 forage pea cultivar - Mir (Pisum sativum L.); 1 milk thistle cultivar - Silmar (Silybum marianum Gaertn.); 1 coriander cultivar - Lozen (Coriandrum sativum L.). The same variants were planted on areas under conventional soil cultivation for each of these crops. After plowing of canola crops, it is more appropriate to sow chickpea in which weed control is carried out by soil treatment with herbicide Merlin flex, followed by foliar treatment with herbicide tank mixture Challenge + Shadow. After plowing areas with damaged by frost winter oilseed canola without any problems can be sown forage pea. Milk thistle and coriander are suitable crops for sowing on areas after damaged by frost winter oilseed canola. The differences in productivities and yield components of chickpea, forage pea, milk thistle and coriander, sown on damaged by frost areas of winter oilseed canola and in normal sowing, are small and mathematically unproven.
\end{abstract}

Key words: chickpea, forage pea, milk thistle, coriander, productivity, yield components

\section{Introduction}

The absence of selection of oilseed canola in our country requires testing of foreign hybrids for use in practice. The large number of canola hybrids is characterized by different winter resistance and adverse weather conditions some hybrids die in winter or their crops severely are diluted (Ivanova and Kolev, 2004; Delchev, 2015). This requires them to be reseeding with other field crops such as chickpea, pea, milk thistle, coriander. The implementation of the biological potential of these crops is closely related to the removal of the harmful effects of weeds (Meena and Mehta, 2009; Tanveer et al., 2010; Ratnam and Rao, 2011; Drapalova and Pluhackova, 2014; Mathukia et al., 2014; Tidemann et al., 2014). The use of herbicides creates favorable conditions for germination, growth and development of these crops and also for the creation of well topped and high-yielding crops (Delchev, 2018, 2020).

The aim of this experiment is to investigate the changes in the productivity and in the yield components in 4 field crops - chickpea, forage pea, milk thistle and coriander sown on damaged by frost crops of winter oilseed canola.

\section{Material and methods}

During 2016 - 2018 was conducted a field experiment on pellic vertisol soil type. It was carried out a field experiment as a block method in 4 repetitions, on a $15 \mathrm{~m}^{2}$ harvesting area.

On areas with damaged by frost winter oilseed canola, at the spring were sowed and investigated: 1 chickpea cultivar - Kabule (Cicer arietinum L.); 1 forage pea cultivar - Mir (Pisum sativum L.); 1 milk thistle cultivar - Silmar (Silybum marianum Gaertn.); 1 coriander cultivar - Lozen (Coriandrum sativum L.). These variants have been sown also on the areas with traditional for each of those crops soil tillage. 
Weed control in chickpea was carried out with herbicide combinations Dual gold 960 EC (S-metolachlor) - 1.5 1/ha + Listego 40 (imazamox) - 1.2 1/ha and Merlin flex $480 \mathrm{SC}$ (isoxaflutole) - $420 \mathrm{~g} / \mathrm{ha}+$ herbicide tank mixture Challenge $600 \mathrm{SC}+$ Shadow $3 \mathrm{EC}$ (aclonifen + clethodim) -4 1/ha +1.6 1/ha. Soil-applied herbicides Dual gold and Merlin flex were treated during the period after sowing before emergence. Foliar-applied herbicides Listego, Challenge and Shadow were treated during 6 - 8 real leaf stage of the chickpea.

Weed control in forage pea was carried out with herbicide combinations Dual gold 960 EC (S-metolachlor) - 1.5 1/ha + Listego 40 (imazamox) - 1.2 1/ha and Stomp aqua (pendimethalin) - 3 1/ha + Korum (bentazone + imazamox) - 1.25 1/ha. Soil-applied herbicides Dual gold and Stomp aqua were treated during the period after sowing before emergence. Foliar-applied herbicides Listego and Korum were treated during 6 - 8 real leaf stage of the pea.

Weed control in milk thistle was carried out with herbicide combination Stomp aqua (pendimethalin) - $31 /$ ha + Stratos ultra (cycloxydim) - 2 1/ha and herbicide tank mixture Zencor $70 \mathrm{WG}+$ Shadow $3 \mathrm{EC}$ (metribuzine + clethodim) $-500 \mathrm{~g} / \mathrm{ha}+1.6 \mathrm{l} / \mathrm{ha}$. Soil-applied herbicide Stomp aqua was treated during the period after sowing before emergence. Foliarapplied herbicides Stratos ultra, Zencor and Shadow were treated during rosette stage of the milk thistle.

Weed control in coriander was carried out with herbicide combination Stomp aqua (pendimethalin) - 31 /ha + Stratos ultra (cycloxydim) - $21 /$ ha and herbicide tank mixture Zencor $70 \mathrm{WG}+$ Shadow $3 \mathrm{EC}$ (metribuzine + clethodim) $-500 \mathrm{~g} / \mathrm{ha}+1.6 \mathrm{l} / \mathrm{ha}$. Soil-applied herbicide Stomp aqua was treated during the period after sowing before emergence. Foliarapplied herbicides Stratos ultra, Zencor and Shadow were treated during rosette stage of the coriander.

Due to of low adhesion of the herbicides Listego and Korum were used in addition with adjuvant Dash $\mathrm{HC}-1$ 1/ha.

It was investigated the changes in seed yields and yield components in these 4 field crops - chickpea, forage pea, milk thistle and coriander. Mathematical data processing was done by the method of analysis of variance.

\section{Results and discussion}

On the area of frozen winter canola was sown chickpea cultivar Kabule. It was found that the reduction in seed yield at sowing after canola compared to normal sowing is mathematically proven only at herbicide combination Dual gold + Listego (Table 1). Reduction is $7 \%-9.9 \%$.

When combining of soil-applied herbicide Merlin flex with herbicide tank mixture Challenge + Shadow, the yield reduction is less and not proved mathematically. The main reason for these differences in yields is the stronger phytotoxicity of herbicide Listego against the chickpea plants, although Listego provides better control of perennial broadleaf weeds compared to the herbicide tank mixture Challenge + Shadow. At combining of soil-applied herbicide Merlin flex with herbicide tank mixture Challenge + Shadow the lesser decrease in yields is due only to the negative influence of shallow tillage and compacted soil after canola. At these two technologies, the high efficiency of the using herbicides is the reason for a good control of weeds in both sowing - after canola and after deep plowing. These results lead to the conclusion that after plowing canola crops is appropriate to sow chickpea in which weed control should be carried out by soil treatment with herbicide Merlin flex, followed by foliar treatment with the herbicide tank mixture Challenge + Shadow. The differences in seed yields in chickpea are due to changes in the values of the indicators number of beans per 1 plant, 
number of seeds per 1 plant and seed weight per 1 plant. The differences between sowing after canola and normal sowing are small and are not mathematically proven in the analysis of variance. The plant height and the first bean height, when chickpea is sown after normal tillage are unproven higher than when sown after frozen canola.

Table 1. Seed yields and yield components of chickpea, grown after damaged by frost winter oilseed canola and in normal sowing (mean 2016 - 2018)

\begin{tabular}{|c|c|c|c|c|c|c|c|}
\hline \multirow{2}{*}{ Variants } & \multicolumn{2}{|c|}{ Seed yield } & \multirow{2}{*}{$\begin{array}{l}\text { Beans } \\
\text { per plant, } \\
\text { number }\end{array}$} & \multirow{2}{*}{$\begin{array}{l}\text { Seeds } \\
\text { per plant, } \\
\text { number }\end{array}$} & \multirow{2}{*}{$\begin{array}{l}\text { Seed } \\
\text { weight } \\
\text { per plant, } \\
\text { g }\end{array}$} & \multirow{2}{*}{$\begin{array}{l}\text { Plant } \\
\text { height, } \\
\mathrm{cm}\end{array}$} & \multirow{2}{*}{$\begin{array}{l}\text { First } \\
\text { bean } \\
\text { height, } \\
\mathrm{cm}\end{array}$} \\
\hline & $\mathrm{kg} / \mathrm{ha}$ & $\%$ & & & & & \\
\hline \multicolumn{8}{|l|}{ Sowing after canola } \\
\hline $\begin{array}{l}\text { Dual gold }+ \\
\text { Listego }\end{array}$ & 1820 & 91.3 & 10.8 & 21.5 & 8.7 & 51.0 & 15.8 \\
\hline $\begin{array}{l}\text { Merlin flex }+ \\
\text { Challenge } \\
\text { Shadow }\end{array}$ & 2124 & 95.5 & 11.9 & 24.0 & 9.6 & 52.2 & 16.4 \\
\hline \multicolumn{8}{|l|}{ Normal sowing } \\
\hline $\begin{array}{l}\text { Dual gold + } \\
\text { Listego }\end{array}$ & 1993 & 100 & 11.4 & 22.9 & 9.1 & 51.0 & 16.0 \\
\hline $\begin{array}{l}\text { Merlin flex }+ \\
\text { Challenge } \\
\text { Shadow }\end{array}+$ & 2224 & 100 & 12.1 & 24.2 & 9.7 & 52.4 & 16.5 \\
\hline LSD 0.5 & 107 & & 1.2 & 2.2 & 1.0 & 4.9 & 2.3 \\
\hline LSD 0.1 & 138 & & 2.6 & 3.6 & 1.7 & 6.4 & 3.8 \\
\hline LSD 0.01 & 171 & & 3.5 & 5.4 & 2.6 & 8.3 & 5.5 \\
\hline
\end{tabular}

On the area of frozen winter canola was sown in early spring forage pea cultivar Mir. Seed yields of forage pea in sowing after canola are lower than those in normal sowing from $1.9 \%$ to $2.5 \%$ (Table 2). The mean yields at herbicide combination Stomp aqua + Korum less in compared to mean yields at herbicide combination Dual gold + Listego.

The reason for this is the longer effect of Korum and its longer control over the secondary-emerged weeds until the pea plants cover the whole soil surface, competes with weeds and almost prevents secondary weed infestation. Unproven differences in seed yields indicate that after plowing of areas with frozen canola hybrids without any problems can be planted forage pea. The differences in seed yields in forage pea are due to changes in the values of the indicators number of beans per 1 plant, number of seeds per 1 plant and seed weight per 1 plant. The differences between sowing after canola and normal sowing are small and are not mathematically proven in the analysis of variance. The plant height and the first bean height, when forage pea is sown after normal tillage are unproven higher than when sown after frozen canola. 
Table 2. Seed yields and yield components of forage pea, grown after damaged by frost winter oilseed canola and in normal sowing (mean 2016 - 2018)

\begin{tabular}{|c|c|c|c|c|c|c|c|c|}
\hline \multirow{2}{*}{ Variants } & & \multicolumn{2}{|c|}{ Seed yield } & \multirow{2}{*}{$\begin{array}{l}\text { Beans } \\
\text { per } \\
\text { plant, } \\
\text { number }\end{array}$} & \multirow{2}{*}{$\begin{array}{l}\text { Seeds } \\
\text { per } \\
\text { plant, } \\
\text { number }\end{array}$} & \multirow{2}{*}{$\begin{array}{l}\text { Seed } \\
\text { weight } \\
\text { per } \\
\text { plant, g }\end{array}$} & \multirow{2}{*}{$\begin{array}{l}\text { Plant } \\
\text { height, } \\
\mathrm{cm}\end{array}$} & \multirow{2}{*}{$\begin{array}{l}\text { First } \\
\text { bean } \\
\text { height, } \\
\mathrm{cm}\end{array}$} \\
\hline & & $\mathrm{kg} / \mathrm{ha}$ & $\%$ & & & & & \\
\hline & \multicolumn{8}{|c|}{ Sowing after canola } \\
\hline $\begin{array}{l}\text { Dual gold + } \\
\text { Listego }\end{array}$ & & 3060 & 97.5 & 12.8 & 59.6 & 9.4 & 124.3 & 76.7 \\
\hline $\begin{array}{l}\text { Stomp aqua + } \\
\text { Korum }\end{array}$ & & 3149 & 98.1 & 13.1 & 59.8 & 10.1 & 125.5 & 74.3 \\
\hline \multicolumn{9}{|c|}{ Normal sowing } \\
\hline $\begin{array}{l}\text { Dual gold + } \\
\text { Listego }\end{array}$ & & 3137 & 100 & 12.9 & 59.8 & 9.7 & 124.6 & 76.8 \\
\hline $\begin{array}{l}\text { Stomp aqua + } \\
\text { Korum }\end{array}$ & & 3209 & 100 & 13.2 & 61.4 & 10.3 & 126.5 & 74.6 \\
\hline LSD 0.5 & & 105 & & 1.1 & 2.0 & 0.9 & 4.3 & 3.0 \\
\hline LSD 0.1 & & 138 & & 2.6 & 3.5 & 1.6 & 5.8 & 4.5 \\
\hline LSD 0.01 & & 173 & & 3.6 & 5.4 & 2.5 & 7.6 & 6.2 \\
\hline
\end{tabular}

On the area of frozen winter canola was sown milk thistle cultivar Silmar. It was found that in both weed control variants the decrease in seed yield in sowing after frozen canola compared to normal sowing is approximately the same (Table 3).

Table 3. Seed yields and yield components of milk thistle, grown after damaged by frost winter oilseed canola and in normal sowing (mean 2016 - 2018)

\begin{tabular}{|c|c|c|c|c|c|c|c|}
\hline \multirow{2}{*}{ Variants } & \multicolumn{2}{|c|}{ Seed yield } & \multirow{2}{*}{$\begin{array}{l}\text { Inflorescen- } \\
\text { ces per } \\
\text { plant, } \\
\text { number }\end{array}$} & \multirow{2}{*}{$\begin{array}{l}\text { Seeds per } \\
\text { inflorescen- } \\
\text { ce, number }\end{array}$} & \multirow{2}{*}{$\begin{array}{l}\text { Seed } \\
\text { weight } \\
\text { per } \\
\text { plant, g }\end{array}$} & \multirow{2}{*}{$\begin{array}{l}1000 \\
\text { seeds } \\
\text { weight, } \\
\mathrm{g}\end{array}$} & \multirow{2}{*}{$\begin{array}{l}\text { Plant } \\
\text { height, } \\
\mathrm{cm}\end{array}$} \\
\hline & $\mathrm{kg} / \mathrm{ha}$ & $\%$ & & & & & \\
\hline \multicolumn{8}{|c|}{ Sowing after canola } \\
\hline $\begin{array}{l}\text { Stomp aqua }+ \\
\text { Stratos ultra }\end{array}$ & 1121 & 96.6 & 4.3 & 80.2 & 8.90 & 29.0 & 132.8 \\
\hline $\begin{array}{l}\text { Zencor + } \\
\text { Shadow }\end{array}$ & 1177 & 97.4 & 4.7 & 81.2 & 9.04 & 29.6 & 133.8 \\
\hline \multicolumn{8}{|l|}{ Normal sowing } \\
\hline $\begin{array}{l}\text { Stomp aqua + } \\
\text { Stratos ultra }\end{array}$ & 1160 & 100 & 4.6 & 80.8 & 9.02 & 29.5 & 133.7 \\
\hline $\begin{array}{l}\text { Zencor }+ \\
\text { Shadow }\end{array}$ & 1208 & 100 & 4.8 & 81.5 & 9.09 & 29.8 & 134.0 \\
\hline LSD 0.5 & 55 & & 0.8 & 2.0 & 0.6 & 2.3 & 3.1 \\
\hline LSD 0.1 & 73 & & 2.2 & 3.4 & 1.3 & 3.8 & 4.6 \\
\hline LSD 0.01 & 100 & & 3.1 & 5.2 & 2.2 & 5.5 & 6.4 \\
\hline
\end{tabular}

It varies from $2.6 \%$ to $3.4 \%$. Due to its powerful root system, the milk thistle is less demanding to the tillage depth than chickpea, pea and coriander. Used herbicide combination and herbicide tank mixture enable effective weed control during crop growing against 
graminaceous and broadleaf weeds. This makes the milk thistle a suitable crop for sowing on areas after frozen winter oilseed canola. The differences in seed yields in milk thistle are due to changes in the values of the indicators number of inflorescences per 1 plant, number of inflorescence per 1 plant, seed weight per 1 plant and 1000 seeds weight. The differences between sowing after canola and normal sowing are small and are not mathematically proven in the analysis of variance. The plant height when milk thistle is sown after normal tillage is unproven higher than when sown after frozen canola.

On the area of frozen winter canola was sown coriander cultivar Lozen. It was found that in both weed control variants the decrease in seed yield in sowing after frozen canola compared to normal sowing is approximately the same (Table 4).

Table 4. Seed yields and yield components of coriander, grown after damaged by frost winter oilseed canola and in normal sowing (mean 2016 - 2018)

\begin{tabular}{|c|c|c|c|c|c|c|c|}
\hline \multirow{2}{*}{ Variants } & \multicolumn{2}{|c|}{ Seed yield } & \multirow{2}{*}{$\begin{array}{l}\text { Umbels } \\
\text { per plant, } \\
\text { number }\end{array}$} & \multirow{2}{*}{$\begin{array}{l}\text { Seeds } \\
\text { per } \\
\text { umbel, } \\
\text { number }\end{array}$} & \multirow{2}{*}{$\begin{array}{l}\text { Seed } \\
\text { weight } \\
\text { per plant, } \\
\text { g }\end{array}$} & \multirow{2}{*}{$\begin{array}{l}1000 \\
\text { seeds } \\
\text { weight, g }\end{array}$} & \multirow{2}{*}{$\begin{array}{l}\text { Plant } \\
\text { height, } \\
\mathrm{cm}\end{array}$} \\
\hline & $\mathrm{kg} / \mathrm{ha}$ & $\%$ & & & & & \\
\hline \multicolumn{8}{|c|}{ Sowing after canola } \\
\hline $\begin{array}{l}\text { Stomp aqua }+ \\
\text { Stratos ultra }\end{array}$ & 2476 & 96.7 & 24.6 & 31.6 & 1.20 & 7.89 & 80.7 \\
\hline $\begin{array}{l}\text { Zencor + } \\
\text { Shadow }\end{array}$ & 2459 & 97.5 & 23.5 & 30.4 & 1.19 & 7.13 & 80.3 \\
\hline \multicolumn{8}{|l|}{ Normal sowing } \\
\hline $\begin{array}{l}\text { Stomp aqua + } \\
\text { Stratos ultra }\end{array}$ & 2562 & 100 & 28.4 & 33.4 & 1.23 & 8.58 & 81.3 \\
\hline $\begin{array}{l}\text { Zencor + } \\
\text { Shadow }\end{array}$ & 2523 & 100 & 27.9 & 32.9 & 1.22 & 8.34 & 81.2 \\
\hline LSD 0.5 & 80 & & 0.9 & 1.9 & 0.7 & 2.1 & 2.2 \\
\hline LSD 0.1 & 101 & & 2.4 & 3.3 & 1.4 & 3.6 & 3.9 \\
\hline LSD 0.01 & 129 & & 3.5 & 5.0 & 2.3 & 5.5 & 6.0 \\
\hline
\end{tabular}

When combining soil-applied herbicide Stomp aqua with foliar-applied herbicide Stratos ultra, yield reduction varies from $2.4 \%$ to $4.7 \%$. At herbicide tank mixture Zencor + Shadow, the yield reduction varies from $2.0 \%$ to $3.5 \%$. In both weed control variants the yield reductions compared to normal sowing and mathematically unproven. This means that coriander is a suitable crop for sowing on areas after damaged by frost winter oilseed canola. The differences in seed yields in coriander are due to changes in the values of the indicators number of umbels per 1 plant, number of seeds per 1 umbel, seed weight per 1 plant and 1000 seeds weight. The differences between sowing after canola and normal sowing are small and are not mathematically proven in the analysis of variance. The plant height when coriander is sown after normal tillage is unproven higher than when sown after frozen canola.

\section{Conclusions}

After plowing of canola crops, it is more appropriate to sow chickpea in which weed control is carried out by soil treatment with herbicide Merlin flex, followed by foliar treatment with herbicide tank mixture Challenge + Shadow. 
After plowing areas with damaged by frost winter oilseed canola without any problems can be sown forage pea.

Milk thistle and coriander are suitable crops for sowing on areas after damaged by frost winter oilseed canola.

The differences in productivities and yield components of chickpea, forage pea, milk thistle and coriander, sown on damaged by frost areas of winter oilseed canola and in normal sowing, are small and mathematically unproven.

\section{Bibliography}

Delchev, G., 2015. Changes in the productivity and the yield structural elements in some spring crops sown on damaged by frost crops of winter oilseed canola. Agricultural Science and Technology, v. 7(3) p. 328-333.

Delchev, G., 2018. Chemical control of weeds and self-sown plants in eight field crops. Monograph, ISBN: 978-613-7-43367-6, LAP LAMBERT Academic Publishing, Saarbrücken, Germany, pp. 397.

Delchev, G., 2020. Winter resistance of oilseed canola and reseeding with spring crops. Monograph, ISBN: 978-620-2-68306-7, LAP LAMBERT Academic Publishing, Saarbrücken, Germany, pp. 129.

Drapalova, I., H. Pluhackova, 2014. Effect of herbicide treatment on milk thistle (Silybum marianum Gaertn.) germination. Conference MendelNet, 19-20 November 2014. Mendel University in Brno, Czech Republic, p. 33-38.

Ivanova, R., T. Kolev, 2004. Testing of introduced canola lines and hybrids in Southern Bulgaria. Plant Science, v. 41(6), p. 504-509.

Mathukia, R., B. Sagarka, D. Panara, 2014. Efficient and economical weed management in coriander (Coriandrum sativum L.). Journal of Crop Science and Technology, v. 3(3) p. 30-33.

Meena, S., R. Mehta, 2009. Integrated weed management in coriander (Coriandrum sativum). Indian Journal of Agricultural Sciences, v. 79(10) p. 824-826.

Ratnam, M.M.; Rao, A.S. 2011. Integrated weed management in chickpea (Cicer arietinum L.). Indian Journal of Weed Science, v. 43(1-2) p. 70-72.

Tanveer, A. Imran, S. Ayub, M. Yasin, M. 2010. Response of chickpea (Cicer arietinum) and Euphorbia dracunculoides to pre- and post-emergence herbicides. Pakistan Journal of Weed Science Research, v. 16(3) p. 267-277.

Tidemann, BD., Hall, LM., Johnson, EN., Beckie, HJ. Sapsford, KL. Raatz, LL. 2014. Efficacy of fall- and spring-applied pyroxasulfone for herbicide-resistant weeds in field pea. Weed Technology, v. 28(2) p. 351-360. 